Journal of the Science of

Food and Agriculture

\title{
Cell wall metabolism of peaches and nectarines treated with UV-B radiation: a biochemical and molecular approach
}

\begin{tabular}{|r|l|}
\hline Journal: & Journal of the Science of Food and Agriculture \\
\hline Manuscript ID: & Draft \\
\hline Wiley - Manuscript type: & Research Article \\
\hline Complete List of Authors: & $\begin{array}{l}\text { Scattino, Claudia; University of Pisa, Department of Agriculture, Food and } \\
\text { Environment } \\
\text { Negrini, Noemi; University of Milan, Department of Agricultural and } \\
\text { Environmental Sciences - Production, Landscape, Agroenergy } \\
\text { Morgutti, Silvia; University of Milan, Department of Agricultural and } \\
\text { Environmental Sciences - Production, Landscape, Agroenergy } \\
\text { Cocucci, Maurizio; University of Milan, Department of Agricultural and } \\
\text { Environmental Sciences - Production, Landscape, Agroenergy } \\
\text { Crisosto, Carlos } \\
\text { Tonutti, Pietro; Scuola Superiore Sant'Anna, Institute of Life Science } \\
\text { Castagna, Antonella; University of Pisa, Department of Agriculture, Food } \\
\text { and Environment } \\
\text { Ranieri, Annamaria; University of Pisa, Department of Agriculture, Food } \\
\text { and Environment }\end{array}$ \\
\hline Key Words: & \begin{tabular}{l} 
peach , UV-B treatment, flesh softening, Endo-PG, expansins, postharvest \\
\hline
\end{tabular} \\
\hline
\end{tabular}


Cell wall metabolism of peaches and nectarines treated with UV-B radiation: a biochemical and molecular approach

\section{Running title: UV-B and flesh firmness in Melting Flesh, Slow Melting Flesh and Non Melting Flesh peach fruits}

Claudia Scattino ${ }^{\mathrm{a}}$, Noemi Negrini ${ }^{\mathrm{b}}$, Silvia Morgutti ${ }^{\mathrm{b}}$, Maurizio Cocucci ${ }^{\mathrm{b}}$, Carlos H. Crisosto ${ }^{\mathrm{c}}$, Pietro Tonutti $^{\mathrm{d}}$, Antonella Castagna ${ }^{\mathrm{a}^{*}}$, Annamaria Ranieri $^{\mathrm{a}}$

${ }^{a}$ Department of Agriculture, Food and Environment, University of Pisa, via del Borghetto 80, 56124 Pisa, Italy

b Department of Agricultural and Environmental Sciences - Production, Landscape, Agroenergy, University of Milan, Via Celoria 2, Milan, Italy

${ }^{c}$ Department of Plant Sciences, University of California at Davis, One Shields Avenue, Davis, CA 95616, USA

${ }^{\mathrm{d}}$ Life Science Institute, Scuola Superiore Sant'Anna, Piazza Martiri della Libertà 33, 56127 Pisa, Italy

* Corresponding author:

phone: +39 (050) 2216608

fax: $+39(050) 2216630$

e-mail: antonella.castagna@unipi.it 


\section{ABSTRACT}

BACKGROUND: UV-B radiation has been shown to improve, at least in selected genotypes, both the health-promoting potential and the aesthetic properties of tomato and peach fruit during their postharvest period. The effects of postharvest UV-B irradiation on the cell wall metabolism of peaches and nectarines (Prunus persica L. Batsch) was assessed in this study. Three cultivars, Suncrest' (Melting Flesh, MF) and 'Babygold 7'(Non-Melting Flesh, NMF) peaches and 'Big Top' (Slow Melting, SM) nectarine, differing for the characteristics of textural changes and softening during ripening, were analysed.

RESULTS: The study shows that UV-B effects differ in relation to the cultivar considered. In MF 'Suncrest' fruits, UV-B treatment significantly reduced the flesh firmness loss despite the slight increase in $P p E n d o-P G$ presence and activity. The UV-B-induced reduction of flesh softening was paralleled by the inhibition of PpExp gene transcription and expansin protein accumulation. The UV-B treatment did not induce differences in flesh firmness between control and UV-B-treated NMF 'Babygold 7' and SM 'Big Top' fruit.

CONCLUSION: Based on these results, UV-B irradiation may be considered a promising tool to improve shelf-life and quality of peach fruits.

KEY WORDS 4-6: peach, UV-B treatment, flesh softening, Endo-PG, expansins, postharvest 


\section{INTRODUCTION}

During fruit storage, the evolution and changes of quality parameters are affected by both intrinsic (genotype) and extrinsic (environment) factors. Among physical treatments useful for maintaining the postharvest quality of fruits and vegetables, UV irradiation demonstrated to be effective in delaying fruit ripening and senescence and in reducing the incidence of postharvest spoilage. UV-C is effective in increasing the antioxidant capacity of strawberries in the postharvest period, in controlling the yellowing of broccoli florets, reducing the incidence of chilling injury in stored peach and pepper. ${ }^{1,2}$ Concerning UV-B (less harmful for the user than UV-C), low and ambient UV-B irradiations inhibit the yellowing of stored green fruits and vegetables and increase the produce antioxidant contents. ${ }^{3,4}$ Recently, it has been shown that postharvest UV-B treatments can improve, at least in selected genotypes, both the healthpromoting potential and the aesthetic properties of tomato and peach fruits by increasing anthocyanin contents. ${ }^{5,6} \mathrm{UV}$ wavelengths may also affect other ripening-related parameters, as firmness that, in strawberries resulted affected by changes in the UV wavelengths transmitted by polythene films in protected cultivation. ${ }^{7}$ Similarly, tomato firmness was influenced by post harvest UV-B irradiation, either in a positive ${ }^{8}$ or in a negative way. ${ }^{5}$ However, information on the effects of postharvest UV irradiation, and in particular of UV-B, on fruit cell wall metabolism is absent.

Peaches and nectarines (Prunus persica L. Batsch) are soft-fleshed drupes with a limited postharvest life. Fruit softening during ripening is the major phenomenon that contributes to fleshy fruit perishability, together with mechanical damage, onset of physiological disorders and decay. The softening process involves multiple co-ordinated events leading to several modifications of the cell wall architecture and involving also transpirational loss of water and cell turgor. ${ }^{9-11}$

A major structural change is the degradation of polyuronides operated by a number of degrading enzymes including polygalacturonases, pectin methylesterases, glycosidases and galactosidases. In the complex process of cell-wall dismantling, a central role is widely acknowledged to endo-acting polygalacturonases (Endo-PGs). ${ }^{12}$ In particular, in ripening peach fruit, Endo-PGs play a key role in determining the melting- 
related phenotype. ${ }^{13-15}$ Cooperatively to those enzymes, expansins (Exp) contribute to cell wall disassembly with a non-enzymatic mechanism. ${ }^{16}$ Expansins are able to loosen the cell wall by disrupting non-covalent linkages at the cellulose/hemicellulose interface, relaxing the constraint to turgor-driven cell expansion. ${ }^{17-19}$ The involvement of these (and other) enzymes has been ascertained also in ripening peach fruit by means of both molecular and biochemical studies. ${ }^{11,14,20-22}$

According to the characteristics of textural changes and softening during ripening, peach fruits are essentially classified as Melting Flesh (MF) and Non-Melting Flesh (NMF). MF peaches are characterized by a rapid loss of flesh firmness (melting) in the last ripening stage in correspondence to the

peak of ethylene biosynthesis. ${ }^{14,23}$ The NMF phenotype softens slowly but never melts despite high ethylene production and shows a firm texture even when the fruit is fully ripe. ${ }^{24,25} \mathrm{NMF}$ fruits, that are traditionally grown for canning purposes, often show a limited development of the red coloration and aroma. ${ }^{26}$ Peculiar softening traits characterize Slow Melting (SM) fruit, such as the 'Big Top' nectarines that retain flesh firmness on the tree for a long time, allowing full development of organoleptic quality. ${ }^{15}$

The present work was aimed to investigate whether a postharvest UV-B treatment was effective in slowing down the flesh softening process in peach and nectarine fruits with different flesh phenotypes (MF 'Suncrest', SM 'Big Top' and NMF 'Babygold 7'). Activities of a few cell wall degrading enzymes, as well as changes in transcript and protein levels of Endo-PGs and Exp were evaluated. Some qualityrelated traits (flesh firmness, SSC, TA, ethylene emission) were measured as well.

\section{EXPERIMENTAL}

\section{Plant material and UV-B treatment}

Peach (Prunus persica L. Batsch) fruits of the yellow-fleshed cultivars 'Suncrest' (Melting, M) and 'Babygold 7' (Non-Melting, NM) and 'Big Top' nectarine ("Slow-Melting”, SM) were harvested in correspondence of flesh firmness values of about $60 \mathrm{~N}$ for MF and SM and about $30 \mathrm{~N}$ for NMF fruits. These flesh firmness values were chosen in order to let the fruits achieve at least the "ready to buy" stage at the end of the experiment, based on flesh firmness evaluations. ${ }^{27}$ 
For each variety about forty-five fruits without defects, selected for uniform size and appearance, were collected and fifteen fruits, representing the $\mathrm{t}_{0}$ sample, were immediately sampled. The remaining fruits were placed for $36 \mathrm{~h}$ in thermo-regulated chambers $\left(20^{\circ} \mathrm{C}\right.$; R.H. $\left.85 \%\right)$, under a photosynthetic photon flux density (PPFD) of $500 \mathrm{~mol} \mathrm{~m}^{-2} \mathrm{~s}^{-1}$ (Powerstar HQI-BT $400 \mathrm{~W} / \mathrm{D}$, Osram, Munich, Germany), in the absence (control fruit) or in the presence (UV-B-treated fruit) of UV-B irradiation. Each chamber was equipped with three UV-B lamp tubes (Philips Ultraviolet B, TL 20W-12RS, Koninklijke Philips Electronics, Eindhoven, The Netherlands), providing at fruit height $1.69 \mathrm{~W} \mathrm{~m}^{-2}$. In the control chamber the UV-B lamps were shielded with benzophenone-treated polyethylene film to block the UV-B radiation. ${ }^{28}$ To ensure uniform UV-B dose, fruits were aligned in rows parallel to the lamp tubes with their peduncle facing down, approximately $40 \mathrm{~cm}$ under the lamps.

At the end of the UV-B treatment, mesocarp samples from the distal part of each fruit (the part directly exposed to UV-B) were pooled, frozen in liquid nitrogen and stored at $-80{ }^{\circ} \mathrm{C}$ for subsequent analyses.

\section{Determination of fruit quality traits}

Fruit flesh firmness (N) was measured, after removing a small disc of skin from the equatorial zone of each cheek, by a digital penetrometer with an 8-mm probe (Model 53205, TR, Forlì, Italy). Total soluble solids content (SSC; ${ }^{\circ}$ Brix) was measured by a digital refractometer (Model 53011, TR). Titratable acidity (TA) was determined by titration of $10 \mathrm{~mL}$ of juice with $0.1 \mathrm{M} \mathrm{NaOH}$ to an endpoint of $\mathrm{pH} 8.2$ by using an automatic Schott Gerate titrator (Model T80/20), and expressed as meq $\mathrm{NaOH} 100 \mathrm{~mL}^{-1}$.

\section{Ethylene measurement}

Ethylene production was quantified in whole, healthy fruits individually incubated in sealed jars (1.2 L) at room temperature $\left(\mathrm{RT} ; 22^{\circ} \mathrm{C}\right)$ for $30 \mathrm{~min}$. Head-space samples $(2 \mathrm{~mL})$ were withdrawn with a hypodermic syringe in a gas chromatograph (HP5890, Hewlett-Packard, Menlo Park, CA) equipped with a dual flame ionization detector (FID) and stainless-steel column (150 x $0.4 \mathrm{~cm}$ internal diameter, packed 
with Hysep T). Column and detector temperatures were $70{ }^{\circ} \mathrm{C}$ and $350{ }^{\circ} \mathrm{C}$, respectively. Nitrogen was used as carrier at a flow rate of $30 \mathrm{~mL} \mathrm{~min}^{-1}$. Ethylene production was expressed as $\mathrm{nL} \mathrm{h}^{-1} \mathrm{~g}^{-1} \mathrm{FW}$.

\section{Cell-wall enzyme extraction and activity assay}

Exo-polygalacturonase (Exo-PG, EC 3.2.1.67), endo-1,4- $\beta$-D-glucanase/ $\beta$-D-glucosidase (EGase, EC 3.2.1.4) and $\beta$-galactosidase ( $\beta$-Gal, EC 3.2.1.23) were extracted according to Manganaris ${ }^{29}$ with some modifications. Frozen samples were homogenized with half volume of $50 \mathrm{mM}$ Na-acetate buffer (pH 5.0), $1 \mathrm{M} \mathrm{NaCl}$ and $10 \%$ polyvinylpolypyrrolidone (PVPP). The homogenate was stirred for $2 \mathrm{~h}$ at $4{ }^{\circ} \mathrm{C}$ and centrifuged $\left(15000 \mathrm{~g}, 30 \mathrm{~min}, 4^{\circ} \mathrm{C}\right)$. The supernatant was collected, dialyzed overnight against the extraction buffer without $\mathrm{NaCl}$ and assayed for enzyme activities at $30{ }^{\circ} \mathrm{C}$ in $1 \mathrm{~mL}$ of a reaction mixture containing $600 \mu \mathrm{L}$ of $37.5 \mathrm{mM}$ Na-acetate buffer $(\mathrm{pH} 4.5)$ and the proper substrates $(0.2 \%$ polygalacturonic acid, $0.2 \%$ carboxymethylcellulose or $10 \mathrm{mM}$ p-nitrophenyl- $\beta$-D-galactopyranoside, for Exo-PG, EGase and $\beta$-Gal, respectively). ${ }^{30}$ The reactions were started by addition of the enzyme extract, and aliquots of the reaction mixture were withdrawn in the course of the subsequent $4 \mathrm{~h}$.

Exo-PG activity was measured by recording the increase in absorbance at $276 \mathrm{~nm}$ due to the generation of reducing ends (2-cyanoacetamide assay), ${ }^{31}$ and expressed as $\mu \mathrm{mol}$ of galacturonic acid $\mathrm{min}^{-1} \mathrm{mg}^{-1} \mathrm{protein}$ EGase activity, generating reducing sugars, was expressed as increase in absorbance at $276 \mathrm{~nm}\left(\Delta \mathrm{Abs}_{276}\right)$ $\min ^{-1} \mathrm{mg}^{-1}$ protein. For $\beta$-Gal activity, aliquots of the reaction mixture were poured into $600 \mu \mathrm{L}$ of $0.4 \mathrm{M}$ $\mathrm{Na}_{2} \mathrm{CO}_{3}$ and the change in absorbance at $400 \mathrm{~nm}$, due to the formation of p-nitrophenol, was recorded. The enzyme activity was expressed as $\mu \mathrm{mol} \cdot \mathrm{p}$-nitrophenol $\mathrm{min}^{-1} \mathrm{mg}^{-1}$ protein.

Pectin methylesterase (PME, E.C. 3.1.1.11) was extracted by homogenizing frozen mesocarp in one volume of $1.5 \mathrm{M} \mathrm{NaCl}$ plus $10 \%$ PVPP. The homogenate was stirred for $10 \mathrm{~min}$ at $4{ }^{\circ} \mathrm{C}$ and centrifuged (15000 $\mathrm{g}, 30 \mathrm{~min}, 4^{\circ} \mathrm{C}$ ). The supernatant was collected and adjusted to $\mathrm{pH} 7.5$. PME activity was determined by measuring the increase in absorbance at $620 \mathrm{~nm}$ of a mixture containing $0.5 \%$ pectin, $0.01 \%$ bromothymol blue in $3 \mathrm{mM}$ phosphate buffer $(\mathrm{pH} 7.5)$ and a proper aliquot of the extract. Activity was expressed as mmol galacturonic acid $\min ^{-1} \mathrm{mg}^{-1}$ protein. 
Endo-PG (E.C. 3.2.1.15) was extracted according to Morgutti. ${ }^{14}$ The frozen samples were homogenized with liquid nitrogen in the presence of 10\% PVPP and four volumes of $1 \mathrm{mM}$ dithiothreitol (DTT) plus 2 $\mathrm{mM}$ phenylmethylsulfonylfluoride (PMSF). After centrifugation $\left(11000 \mathrm{~g}, 20 \mathrm{~min}, 4^{\circ} \mathrm{C}\right)$, the cell wallenriched pellet was washed with four volumes of the same solution and re-centrifuged. The pellet was suspended $\left(1 \mathrm{~mL} \cdot \mathrm{g}^{-1}\right.$ initial $\left.\mathrm{FW}\right)$ in high-salt extraction buffer, $\mathrm{pH} 5.5$ [40 mM Na-acetate, $1.5 \mathrm{M} \mathrm{NaCl}$, $20 \mathrm{mM} \beta$-mercaptoethanol ( $\beta$-ME), $2 \mathrm{mM} \mathrm{PMSF}]$, stirred overnight at $4^{\circ} \mathrm{C}$ and centrifuged $(11000 \mathrm{~g}, 30$ min, $4^{\circ} \mathrm{C}$ ) twice to completely eliminate tissue debris. The supernatant was filtered (Amicon Ultra Centrifugal Filters Ultracel-10K - Regenerated cellulose, 10000 MWCO, Millipore, Billerica, MA) with two volumes of the extraction buffer without $\mathrm{NaCl}$ and stored at $-80^{\circ} \mathrm{C}$.

Expansins were extracted homogenizing frozen mesocarp with one volume of extraction buffer, $\mathrm{pH} 7.5$ [100 mM Tris- $\mathrm{HCl}, 5 \mathrm{mM} \mathrm{MgCl}_{2}, 7 \mathrm{mM} \beta-\mathrm{ME}, 2 \mathrm{mM}$ PMSF, 0.025\% Triton X-100, $1 \mathrm{mM}$ ethylenediaminetetraacetic acid (EDTA), 10\% PVPP]. After centrifugation (9600 g, $\left.40 \mathrm{~min}, 4^{\circ} \mathrm{C}\right)$, the pellet was washed twice with the extraction buffer, suspended in one volume of denaturing buffer, $\mathrm{pH} 6.8$ [100 mM Tris-HCl, 4\% sodium dodecyl sulfate (SDS), 5\% $\beta$-ME, 20\% glycerol, $4 \mathrm{mM}$ PMSF] and heated $\left(90^{\circ} \mathrm{C}, 20 \mathrm{~min}\right)$. The expansins-enriched supernatant was recovered after centrifugation $(9000 \mathrm{~g}$, $40 \min , 4^{\circ} \mathrm{C}$ ) and stored at $-80^{\circ} \mathrm{C} .{ }^{32}$

The protein content was determined using bovine serum albumin as a standard (Bio-Rad Protein Assay; Bio-Rad Laboratories, Segrate, Italy $)^{33}$. For expansins-enriched extracts, proteins were quantified by PlusOne 2-D Quant Kit (GE Healthcare SRL, Milan, Italy).

\section{Electrophoretic and western blot analysis of Endo-PG and expansins}

PG activity was visualized by specific staining ${ }^{14,34}$ following native-PAGE $(10 \%)$ carried out in a MiniProtean apparatus (Bio-Rad Laboratories,. Segrate, Italy). SDS-PAGE $(10 \%)^{35}$ was performed in a MiniProtean apparatus, after denaturation of salt-extracted proteins in SDS sample buffer. ${ }^{36}$ Molecular weight markers were Full-Range Rainbow Molecular Weight Markers RPN800E (GE Healthcare SRL, Milan, Italy). Western blot analysis was conducted as previously described ${ }^{14}$ using rabbit anti-Endo- 
PG polyclonal antibodies (Primm S.r.l. Milano, Italy) raised against a synthetic polypeptide, able to recognize an active form of the enzyme, ${ }^{14,15}$ constructed on a conserved region of the complete sequence of a Pp-endo-PG from ripe peach fruit (CAA54150). ${ }^{14,37}$ Expansins were detected using a 1:1500 dilution of polyclonal antibodies against a purified form of expansin (Expansin1 from Lycopersicon esculentum, Anti-LeExp1 antibodies) ${ }^{38}$, acknowledged to recognize peach expansins as well. ${ }^{39,40}$

\section{Gene expression}

Total RNA was isolated from freeze-dried mesocarp using E.Z.N.A. ${ }^{\circledR}$ SQ Total RNA Kit (Omega BioTek Inc, Norcross, GA, USA) according to the manufacturer's instructions. Samples were concentrated to a volume of $20 \mu \mathrm{L}$ using the RNA Clean \& Concentrator ${ }^{\mathrm{TM}}-5$ (Zymo Research, Orange, CA, USA). RNA integrity was visually inspected on a $1 \%$ agarose gel (MOPS Buffer/Formaldehyde Protocol) ${ }^{41}$ and quantified and assessed for purity using an Eppendorf BioPhotometer (Eppendorf, Hamburg, Germany). First-strand cDNA was synthesized from about $1 \mu \mathrm{g}$ of total RNA with the QuantiTect Reverse Transcription kit (Qiagen, Hilden, Germany). Quantitative Real Time PCR (qRT-PCR) was conducted using the StepOnePlus ${ }^{\mathrm{TM}}$ procedure (Applied Biosystems, Foster City, CA, USA), using SYBR ${ }^{\circledR}$ Green, in a total reaction volume of $15 \mu \mathrm{L}$ containing $2 \mu \mathrm{L}$ of template (diluted 1:5), $0.5 \mu \mathrm{L}$ of reverse and forward primers (Table 1; final primer concentration $10 \mu \mathrm{M}$ ), $7.5 \mu \mathrm{L}$ iTaq ${ }^{\mathrm{TM}} \mathrm{SYBR}^{\circledR}$ Green Supermix with ROX (Bio-Rad Laboratories, Hercules, CA, USA), and 4.5 $\mu \mathrm{L}$ of RNA-free water. Conditions for the qRT-PCR assay were: $95^{\circ} \mathrm{C}$ for $10 \mathrm{~min}$ followed by 40 cycles of $95{ }^{\circ} \mathrm{C}$ for $30 \mathrm{~s}$ and $60{ }^{\circ} \mathrm{C}$ for $30 \mathrm{~s}$. Relative gene expression was calculated using the $2^{-\Delta \Delta C t}$ method $^{42}$ using actin gene as the reference. Average expression levels for each RNA were determined from the highly consistent triplicate reactions, with the range of the reactions never higher than 0.5 threshold cycle $(\mathrm{Ct})$. PpEndo- $P G$ gene specific primers were designed on the sequences reported by Gonzales-Aguero. ${ }^{43}$ The primer sets used for assessment of PpExp1, PpExp2 and PpExp3 gene expression were designed on the sequences reported by Pegoraro. ${ }^{44}$ Actin primers were designed on the sequences reported by El-Sharkawy (Table 1$) .{ }^{45}$ 


\section{Statistical analysis}

Data were subjected to one-way analysis of variance (ANOVA) using the NCSS 2000 (NCSS Statistical Software, Kaysville, UT, USA) software. Significant differences between UV-B treated and control fruits were calculated using at least three replicates, according to Tukey’s test $(\mathrm{P} \leq 0.05)$.

\section{RESULTS}

\section{Fruit quality traits and ethylene production}

Data about fruit quality traits and ethylene production are shown in Table 2. At the beginning of the experiment $\left(\mathrm{t}_{0}\right)$, the average flesh firmness of MF 'Suncrest' and SM 'Big Top' fruits was essentially similar and remarkably high. After $36 \mathrm{~h}$, flesh firmness decreased in control fruits of both cultivars, to a different extent according to MF or SM phenotype. NMF 'Babygold 7' fruits, although showing at $t_{0}$ the lowest firmness, did not undergo marked changes of this parameter after $36 \mathrm{~h}$. The UV-B treatment significantly reduced flesh softening in MF fruits, whose firmness was $64 \%$ higher as compared to control, while UV-B did not affect this parameter in both SM and NMF fruits.

At $\mathrm{t}_{0}$, the highest and the lowest SSC values were measured in SM 'Big Top' and NMF 'Babygold 7', respectively. This parameter did not change after post harvest conservation nor following UV-B treatment in any cultivar.

MF fruits exhibited the highest TA at $\mathrm{t}_{0}$, whereas lower and essentially similar values were observed in SM and NMF fruits. In any cultivar, TA remained unchanged after $36 \mathrm{~h}$ under both control and UV-B treatment conditions, with the exception of MF fruits, where it decreased significantly after UV-B exposure (-39\% compared to control).

Ethylene evolution at $t_{0}$ was very high in NMF, lower in MF, and barely detectable in SM fruits. After 36 h, MF and, even more, SM control fruits showed a dramatic increase (about $+200 \%$ and $+5000 \%$, respectively, compared to $t_{0}$ ) in ethylene production. Ethylene emission was significantly induced by UVB treatment in $\mathrm{MF}(+51 \%)$ and to an even greater extent $(+72 \%)$ in SM fruit, as compared to the 
respective controls. In NMF fruits, after $36 \mathrm{~h}$, ethylene production appeared essentially unchanged in controls and showed a not-significant increasing trend in UV-B treated samples.

\section{Exo-polygalacturonase, endo-1,4- $\beta$-D-glucanase/ $\beta$-D-glucosidase, $\beta$-Galactosidase and pectin methylesterase activities}

To elucidate whether UV-B exposure could affect peach cell-wall metabolism, the in vitro activities of a few enzymes whose role in fruit cell-wall degradation is widely acknowledged (i.e. Exo-PG, EGase, $\beta$ Gal, PME $)^{12}$ were studied. At $t_{0}$, Exo-PG activity was different in the three cultivars, being the lowest in SM 'Big Top' and the highest in NMF 'Babygold 7'. Exo-PG activity increased after $36 \mathrm{~h}$ in control MF and SM fruits, whereas it remained unchanged in NMF after $36 \mathrm{~h}$ in both control and UV-B-treated fruits. The UV-B treatment induced significant increases in MF and SM activity $(+31 \%$ and $+37 \%$, respectively, compared to control conditions; Figure 1A). EGase activity was the highest, at $\mathrm{t}_{0}$, in MF 'Suncrest' fruits and much lower in SM and NMF. After 36 h EGase activity was found to increase in control MF fruits, while UV-B treatment significantly increased EGase activity levels only in SM $(+43 \%$ compared to control fruits; Figure 1B).

$\beta$-Gal activity at $t_{0}$ was lower in MF and SM compared to NMF. The enzyme activity did not significantly change after $36 \mathrm{~h}$ in control samples, nor it was affected by the UV-B treatment (Figure 1C). No effect of UV-B treatment on PME activity of the three varieties was also observed (Figure 1D).

\section{Endo-PG and expansins proteins}

The anti-PpEndo-PG antibodies reacted with a polypeptide of about $45 \mathrm{kDa}$ (PpEndo-PG; Figure 2A), consistent with the molecular mass reported for catalytically active PG forms. ${ }^{46}$ At $t_{0}$, PpEndo-PG was not detectable in any of the three cultivars, independently of flesh firmness (ranging from $57 \mathrm{~N}$ in $\mathrm{MF}$ and $\mathrm{SM}$ to $28 \mathrm{~N}$ in NMF, Table 2). After $36 \mathrm{~h}$, PpEndo-PG was more abundant in the MF (11 N flesh firmness) than in the SM (36 N flesh firmness) control fruits. In both MF and SM the levels of PpEndo- 
PG were slightly increased by the UV-B treatment. In NMF fruit, PpEndo-PG remained undetectable after the $36 \mathrm{~h}$ of postharvest in both control and UV-B-treated fruits (Figure 2A, C).

To ascertain whether the PpEndo-PG protein level was associated to Endo-PG activity, in gel enzyme activity was monitored. At $\mathrm{t}_{0}$ Endo-PG activity was not detectable in any cultivar. In MF 'Suncrest' gel discoloration ascribable to Endo-PG activity became apparent after $36 \mathrm{~h}$ in control conditions and was slightly enhanced by the UV-B treatment. A similar although less pronounced behavior was observed in SM ‘Big Top' fruit while Endo-PG activity was never detectable in NMF (Figure 2B).

The anti-LeExp1 antibodies immunoreacted with a polypeptide band of about $27 \mathrm{kDa}$, consistent with the molecular mass reported for peach expansins. ${ }^{39,40}$ At $t_{0}$, the expansin signal was absent or barely detectable, but after $36 \mathrm{~h}$ it became clearly visible in control fruits of MF, as well as, to a lesser extent, of SM. UV-B treatment lowered expansins levels in MF fruits and slightly increased them in SM, compared to the controls. In NMF, no expansins could be detected both in the absence and in the presence of UV-B treatment (Figure 3).

\section{Expression levels of a PpEndo-PG gene and of PpExp genes}

In MF and SM the PpEndo-PG transcripts were low at $\mathrm{t}_{0}$ and increased after $36-\mathrm{h}$ in control fruits, to a greater extent in MF than in SM (about seven- and two-fold, respectively). In neither of the two cultivars UV-B treatment significantly affected the transcripts levels. In NMF fruits, $P p E n d o-P G$ transcripts could not be detected with the used primers, at any time and in any condition.

In peach, three expansin genes (PpExp1, PpExp2, PpExp3) have been identified and described. ${ }^{47}$ The relative expression levels of PpExp1 and PpExp2 remained constant after $36 \mathrm{~h}$ in MF and SM control fruits, whereas they significantly increased in NMF. After the UV-B treatment, $P p \operatorname{Exp} 1$ and $P p E x p 2$ were significantly less transcribed than in the corresponding control, particularly in NMF. The relative expression levels of PpExp3, i.e. the gene proposed to be mostly involved in peach softening, ${ }^{47}$ increased significantly during the postharvest period in control fruit of all three cultivars. The 36-h UV-B treatment blocked the postharvest-related increase in PpExp3 transcript levels in MF and inhibited it in SM. In 
NMF fruits the PpExp3 expression levels were dramatically lower in UV-B treated fruits than in the corresponding control, and even lower than at $\mathrm{t}_{0}$ (Table 3 ).

\section{DISCUSSION}

Soluble solids content (SSC) and titratable acidity (TA) are important determinants of fruit quality affecting the consumer's perception of sweetness and sourness and the produce marketability. ${ }^{48,49}$ Since consumer's acceptance for peach appears to be more sensitive to the SSC/TA ratio than to the absolute SSC values, ${ }^{50}$ the higher SSC/TA ratios induced by the UV-B treatment in MF fruits suggests the possibility to use this radiation to improve fruit quality. The observed effects of UV-B treatment seem to act in an opposite direction than UV-C rays, which are reported to reduce the SSC/TA ratio in apple fruits. $^{51}$

Flesh firmness is an indicator of the ripening stage and a reliable predictor of fruit behavior during the shelf life, being related to fruit susceptibility to mechanical damage and microorganism spoilage. ${ }^{52}$ Flesh firmness ranges are given in the literature to define the requirements for peach harvest ("ready to buy" fruit, $26.5 \mathrm{~N}-35.3 \mathrm{~N}$ ) and retail marketability ("ready to eat" fruit, $8.8 \mathrm{~N}-13.2 \mathrm{~N}$ ).. ${ }^{53}$ The EU rules set the maximum firmness for commercial harvest of peaches at $63.7 \mathrm{~N} .^{54}$ Fruits of MF and SM showed, at harvest, very high values of flesh firmness, close to the EU-set threshold. The quick decrease in this parameter observed in MF control fruits and the less rapid decrease detected in SM were consistent with the widely acknowledged behavior of these fruit types. ${ }^{15,55}$ NMF peaches differ from MF since they do not undergo the characteristic "melting" stage. ${ }^{37,56}$ Despite NMF fruits showed lower flesh firmness than MF at harvest, this parameter was maintained essentially constant after 36-h, consistent with evidences on the narrower changes in flesh firmness of NMF fruits compared to $\mathrm{MF}^{25,57}$ A similar behavior was observed in the NMF cultivar 'Oro A' (D. Gabotti, personal communication). Reports are available on the effects of UV-C radiation in contrasting flesh firmness decrease during shelf life in apple ${ }^{58}$ and tomato $^{59,60}$; in this last species the effect was accompanied by the inhibition of the synthesis/expression of 
cell wall-degrading enzymes. ${ }^{60}$ Conflicting results have been reported on the effects of UV-B on fruit firmness. In tomato cultivar 'Zhenfen 202', UV-B irradiation allowed the maintenance of a significantly higher flesh firmness, ${ }^{8}$ whereas in the cultivar 'Money maker' and in the 'high pigment-1' mutant softening was enhanced by UV-B treatment. ${ }^{5}$ These opposite effects were probably due to different irradiation doses or modalities in addition to possible, still unknown, different genotype-related anatomical features (e.g., skin morphology and characteristics) and/or biochemical/physiological mechanisms. In the present study, however, the UV-B irradiation conditions were homogeneous for all the three peach cultivars, suggesting that the different UV-B effects (significant inhibition of flesh softening in MF fruits and no effect in SM and NMF ones) might be linked to a genotype-dependent response.

Ethylene is involved in the trigger and regulation of the ripening process in climacteric fruits, including peach, as well as in the plant response to several stress signals. ${ }^{61}$ According to literature, NMF fruits evolved higher amounts of ethylene than MF and, even more, than SM. ${ }^{15,24,62,63}$ UV-B irradiation, in the conditions adopted in the present study, generally induced enhanced ethylene emission, probably acting as a stress factor. This phytoregulator has been suggested to be involved in the signaling pathway of UV$\mathrm{B}$, which induced enhanced ethylene production in green tissues of oat, tobacco, tomato, pear and Arabidopsis thaliana. ${ }^{64}$ Consistently, in tomato fruits grown under UV-B deprivation, a marked decrease in ethylene production has been described. ${ }^{65}$

Dismantling of the cell-wall architecture, due to changes in expression/activity of cell-wall localized enzymes acting on specific (mainly polysaccharide) components of this structure, is an important determinant of texture changes during ripening of fleshy fruits ${ }^{21,46,61}$ and is often controlled by ethylene ${ }^{66}$. Polygalacturonases and pectin methylesterase are considered as the primary degrading enzymes involved in the softening process. Their action is accompanied by other hydrolytic enzymes such as cellulase and $\beta$-D-galactosidase. ${ }^{12,50}$ It is widely accepted that PGs (exo- and endo- acting) play a key role in peach flesh softening, their different presence/activity determining the MF/SM/NMF fruit phenotype. ${ }^{13-15,37}$ 
Our results concerning PG activity appear somewhat conflicting with this widely accepted knowledge. In fact, in UV-B-irradiated MF fruits, the significantly diminished loss of firmness is accompanied by increased activity of both Exo-PG and Endo-PG and substantial invariance of EGase, $\beta$-Gal and PME. A slight discrepancy between PG activity and changes in flesh firmness was detectable also in SM fruit, where lack of UV-B effect on firmness was accompanied by increased activities of Exo-PG and, even if to a slight extent, Endo-PG. It is interesting to note that NMF fruits showed the highest Exo-PG activity at harvest, consistent with data of the literature. ${ }^{67,68}$ In control conditions, the changes in Endo-PG activity in MF and SM fruits after $36 \mathrm{~h}$ of postharvest were accompanied by changes in the levels of a PpEndo-PG protein and the corresponding $P p E n d o-P G$ gene transcripts.

In NMF fruits, the absence of the PpEndo-PG protein was accompanied by the complete lack of expression of $P p E n d o-P G$ gene, consistent with literature reports. ${ }^{37,69}$ A different behavior has been instead reported for another NMF peach cultivar, 'Oro A', where the accumulation of $P p E n d o-P G$ transcripts accompanied by very low protein levels suggested post-transcriptional regulation of PpEndoPG synthesis. ${ }^{14}$ The UV-B treatment had different effects on PpEndo-PG levels and activities, that increased in both MF and SM fruits, and $P p E n d o-P G$ gene expression, that were unaltered, compared to the related controls. The stability of $P p E n d o-P G$ mRNAs seems therefore unaffected by UV-B, whereas it may be speculated that the higher protein levels can be due to lower protein degradation under UV-B radiation by presently unknown mechanism(s).

Expansins are also involved in the ripening-associated fruit softening, being detected in several ripe fruits concomitant with the expression of the related expansin genes. In particular, LeExpl gene transcription increases during tomato ripening: ${ }^{70}$ peach PpExp 1 and PpExp2 are constitutively expressed in postharvest in both MF and SH fruit, whereas the expression of PpExp3 appears involved in the regulation of fruit softening. ${ }^{47}$ Consistently, in the present work, PpExp1 and PpExp2 gene expression remained unchanged in control MF fruits after $36 \mathrm{~h}$, whereas PpExp3 transcript levels increased significantly, parallel to the appearance of expansin protein and increased flesh softening. A similar trend was observed in SM fruit. 
In NMF control fruits, the increased expression of all PpExp genes after $36 \mathrm{~h}$, accompanied by the absence of the related proteins, is consistent with observations in NMF cultivar 'Oro A' ${ }^{71}$ suggesting that post-transcriptional mechanisms may be involved in the regulation of expansin levels. Further studies are however necessary to clarify this point.

In the ripening process, expansin genes expression and protein accumulation are differently sensitive to ethylene, depending to the non-climacteric or climacteric nature of the fruit. In strawberry, a nonclimacteric fruit, the $\alpha$-expansin gene FaExp2 is insensitive to ethylene, while in tomato (climacteric) the expression of the $\alpha$-expansin gene LeExpl is up-regulated by endogenous and exogenous ethylene,$^{72}$ and in $\mathrm{SH}$ peach, which do not spontaneously produce ethylene, ${ }^{15}$ expression of PpExp3 occurs only upon ethylene treatment. ${ }^{47}$ In the present work, although ethylene emission was enhanced upon UV-B treatment, PpExp gene expression was generally inhibited. This result, together with the generally observed decrease of PpExp transcripts in UV-B-treated compared to freshly harvested fruits, may be tentatively explained by hypothesizing a specific inhibitory effect, through so far unknown mechanism(s), of UV-B not only on gene transcription but also on transcript stability. The latter hypothesis may also explain the observed discrepancy between PpExp genes expression levels and presence of PpExp protein, particularly evident in NMF fruit.

On the basis of the acknowledged involvement of PpExp3 in fruit softening, its diminished expression, paralleled by the effect on related protein, may at least partially account for the decrease in fruit softening observed in UV-B-treated MF fruit. This is consistent with results obtained in tomato, where diminished expression of a ripening-regulated expansin, LeExpl, reduces fruit softening, ${ }^{16}$ and suppression of LeExpl increases fruit firmness. ${ }^{16,32}$

Expansins were detected in peach already at $70 \mathrm{~N}$ flesh firmness ('Autumn Red' cultivar) ${ }^{40}$. Hayama ${ }^{73}$ reported the presence of expansins at about $45 \mathrm{~N}$ (SH 'Yumyeong') and $30 \mathrm{~N}$ (MF 'Akatsuki'). With the same anti-LeExp1 antibodies used by these authors, we could not detect expansins in MF at $57 \mathrm{~N}$, but observed a slight immunoreaction signal in SM at the same flesh firmness. We hypothesize that this result 
is due to cultivar-related specificities in the regulation of expansin synthesis, possibly involving posttranscriptional events, as suggested by the described discrepancy between PpExp transcriptional activity and expansin levels.

\section{CONCLUSIONS}

Taken as a whole, our results seem to indicate, at least preliminarily, that UV-B irradiation may represent a promising nonchemical tool to improve the postharvest shelf life of peach commodities, with particular regard to MF fruit, by slowing down flesh softening. A slighter effect on the organoleptic properties of the flesh cannot be excluded, as suggested by increase in the SSC/TA ratio.

Further investigation is needed to ascertain whether our results, observed in a single MF cultivar, can be generalized to other cultivars with the same flesh texture properties.

\section{ACKNOWLEDGEMENTS}

This work was supported by the European Cooperation in the field of Scientific and Technical Research, COST Action FA0906: "UV-B radiation: A specific regulator of plant growth and food quality in a changing climate" and by funds of the University of Pisa. The authors thank Prof. J.K.C. Rose, Cornell University, NY, for the kind gift of LeExp1 antibodies.

\section{REFERENCES}

1) Gonzalez-Aguilar G, Wang CY and Buta GJ, UV-C irradiation reduces breakdown and chilling injury of peaches during cold storage. J Sci Food Agric 84: 415-422 (2004).

2) Ribeiro C, Canada J and Alvarenga B, Prospects of UV radiation for application in postharvest technology. Emir J Food Agric 24: 586-597 (2012). 
3) Liu C, Jahangir MM and Ying $\mathrm{T}$, Alleviation of chilling injury in postharvest tomato fruit by preconditioning with ultraviolet irradiation. J Sci Food Agric 92: 3016-3022 (2012).

4) Yamauchi N, Quality maintenance of postharvest horticultural crops by stress treatments and approach for the elucidation of its mechanism. J Japan Soc Hort Sci 82: 1-10 (2013).

5) Castagna A, Dall'Asta C, Chiavaro E, Galaverna G and Ranieri A, Effect of postharvest UV-B irradiation on polyphenol profile and antioxidant activity in flesh and peel of tomato fruits. Food Chem 137: 151-158 (2013).

6) Scattino C, Castagna A, Neugart S, Chan HM., Schreiner M, Crisosto CH et al., Post-harvest UV-B irradiation induces changes of phenol contents and corresponding biosynthetic gene expression in peaches and nectarines. Food Chem 163: 51-60 (2014).

7) Ordidge M, García-Macías P, Battey NH, Gordon MH, John P, Lovegrove JA et al., Development of colour and firmness in strawberry crops is UV light sensitive, but colour is not a good predictor of several quality parameters. J Sci Food Agric 92: 1597-160 (2012).

8) Liu C, Han X, Cai L, Lu X, Ying T and Jiang Z, Postharvest UV-B irradiation maintains sensory qualities and enhances antioxidant capacity in tomato fruit during storage. Postharvest Biol Technol 59: 232-237 (2011).

9) Saladié M, Matas AJ, Isaacson T,. Jenks MA, Goodwin SM,. Niklas KJ et al., A re-evaluation of the key factors that influence tomato fruit softening and integrity. Plant Physiol 144: 1012-1028 (2007).

10) Vicente AR, Saladié M, Rose JK and Labavitch JM, The linkage between cell wall metabolism and fruit softening: looking to the future. J Sci Food Agric 87: 1435-1448 (2007).

11) Ghiani A, Negrini N, Morgutti S, Baldin F, Nocito FF, Spinardi A et al., Melting of 'Big Top' nectarine fruit: some physiological, biochemical, and molecular aspects. J Amer Soc Hort Sci 136: 61-68 (2011).

12) Rose JKC, Català C, Gonzalez-Carranza ZH, Roberts JA, Cell wall disassembly, in The Plant Cell Wall, Annual Plant Reviews, Volume 8, ed. by Rose JKC. Wiley-Blackwell, pp. 264-324 (2003). 
13) Cahallan AC, Scorza R, Basset $C$, Nickerson $M$ and Abeles FB, Deletions in an endopolygalacturonase gene cluster correlated with non-melting flesh texture in peach. Funct Plant Biol 31: 159-168 (2004).

14) Morgutti S, Negrini N, Nocito FF, Ghiani A, Bassi D and Cocucci M, Changes in endopolygalacturonase levels and characterization of a putative endo- $P G$ gene during fruit softening in peach genotypes with nonmelting and melting flesh fruit phenotypes. New Phytol 171: 315-328 (2006).

15) Ghiani A, Onelli E, Aina R, Cocucci M and Citterio S, A comparative study of melting and nonmelting flesh peach cultivars reveals that during fruit ripening endopolygalacturonase (endo-PG) is mainly involved in pericarp textural changes, not in firmness reduction. $J$ Exp Bot 62: 4043-4054 (2011).

16) Powell ALT, Kalamaki MS, Kurien PA, Gurrieri S and Bennett AB, Simultaneous transgenic suppression of $L e P G$ and LeExpl influences fruit texture and juice viscosity in a fresh market tomato variety. J Agric Food Chem 51: 7450-7455 (2003).

17) McQueen-Mason SJ and Cosgrove DJ, Disruption of hydrogen bonding between wall polymers by proteins that induce plant wall extension. Proc Natl Acad Sci USA 91: 6574-6578 (1994).

18) Cosgrove (2003). Expansion of the plant cell, in: The Plant Cell Wall, Annual Plant Reviews, Volume 8, ed. by Rose JKC. Wiley-Blackwell, pp. 237-263 (2003).

19) Lipchinsky A, How do expansins control plant growth? A model for cell wall loosening via defect migration in cellulose microfibrils. Acta Physiol Plant 35: 3277-3284 (2013).

20) Trainotti L, Zanin D and Casadoro G, A cell wall-oriented genomic approach reveals a new and unexpected complexity of the softening in peaches. $J$ Exp Bot 54: 1821-1832 (2003).

21) Brummell DA, Dal Cin V, Crisosto $\mathrm{CH}$ and Labavitch JM, Cell wall metabolism during maturation, ripening and senescence of peach fruit. J Exp Bot 55: 2029-2039 (2004). 
22) Trainotti L, Bonghi C, Ziliotto F, Zanin D, Rasori A, Casadoro G et al., The use of microarray $\mu \mathrm{PEACH} 1.0$ to investigate transcriptome changes during transition from pre-climacteric to climacteric phase in peach fruit. Plant Sci 170: 606-613 (2006).

23) Tonutti P, Bonghi $\mathrm{C}$ and Ramina A, Fruit firmness and ethylene biosynthesis in three cultivars of peach (Prunus persica L. Batsch.). J Hort Sci 71:141-147 (1996).

24) Brovelli EA, Brecht JK, Sherman WB and Sims CA, Nonmelting-flesh trait in peaches is not related to low ethylene production rates. HortScience 34: 313-315 (1999).

25) Bassi D and Monet R, Botany and taxonomy, in: The peach: Botany, production and uses, ed. by Layne DR and Bassi D. CAB Intl., Wallingford, UK, pp. 1-36 (2008).

26) Brovelli EA, Brecht JK, Sherman WB, Sims CA and Harrison JM, Sensory and compositional attributes of melting- and non-melting-flesh peaches for the fresh market. J Sci Food Agr 79: 707712 (1999).

27) Crisosto $\mathrm{CH}$, How do we increase peach consumption? Proceedings of 5th International Symposium on Peach, ISHS, Acta Hort 592: 601-605 (2002).

28) Giuntini D, Lazzeri V, Calvenzani V, Dall'Asta C, Galaverna G, Tonelli C et al., Flavonoid profiling and biosynthetic gene expression in flesh and peel of two tomato genotypes grown under uv-bdepleted conditions during ripening. J Agric Food Chem 56: 5905-5915 (2005).

29) Manganaris GA, Vicente AR, Crisosto $\mathrm{CH}$ and Labavitch JM, Cell wall modifications in chilling injured plum fruit (Prunus salicina). Postharvest Biol Technol 48: 77-83 (2008).

30) Manganaris GA, Vicente AR, Crisosto CH, Labavitch JM, Effect of dips in a 1-Methylcyclopropenegenerating solution on 'Harrow Sun' plums stored under different temperature regimes. J Agric Food Chem 55: 7015-7020 (2007).

31) Gross KC, A rapid and sensitive spectrophotometric method for assaying polygalacturonase using 2cyanoacetamide. Hort Sci 17: 933-934 (1982). 
32) Brummell DA, Harpster MH, Civello PM, Palys JM, Bennett AB and Dunsmuir P, Modification of expansin protein abundance in tomato fruit alters softening and cell wall polymer metabolism during ripening. Plant Cell 11: 2203-2216 (1999).

33) Bradford MM, A rapid and sensitive method for the quantitation of microgram quantities of protein utilizing the principle of protein-dye binding. Anal Biochem 72: 248-254 (1976).

34) Moore T, Bennett AB, Tomato fruit polygalacturonase isozyme 1. Plant Physiol 106: 1461-1469 (1994).

35) Schagger $\mathrm{H}$ and von Jagow G, Tricine-sodium dodecyl sulfate-polyacrylamide gel electrophoresis for the separation of proteins in the range from 1 to $100 \mathrm{kDa}$. Anal Biochem 1: 368-379 (1987).

36) Laemmli UK, Cleavage of structural proteins during the assembly of the head of bacteriophage T4. Nature 227: 680-685 (1970).

37) Lester DR,. Sherman WB and Atwell BJ, Endopolygalacturonase and the melting flesh (M) locus in peach. J Amer Soc Hort Sci 121: 231-235 (1996).

38) Rose JKC, Cosgrove OJ, Albersheim P, Darvill AG, Bennett AB, Detection of expansin proteins and activity during tomato fruit ontogeny. Plant Physiol 123: 1583-1592 (2000).

39) Hayama H, Shimada T, Haji T, Ito A, Kashimura $Y$ and Yoshioka H, Molecular cloning of a ripening-related expansin cDNA in peach: evidence for no relationship between expansin accumulation and change in fruit firmness during storage. J Plant Physiol 57: 567-573 (2000).

40) Obenland DM, Crisosto $\mathrm{CH}$ and Rose JKC, Expansin protein levels decline with the development of mealiness in peaches. Postharvest Biol Technol 29: 11-18 (2003).

41) Maniatis T, Fritsch EF and Sambrook J, Molecular cloning: a laboratory manual. Cold Spring Harbor Laboratory, Cold Spring Harbor, N.Y. (1982)

42) Livak KJ and Schmittgen TD, Analysis of relative gene expression data using realtime quantitative PCR and the 2-bbCT method. Methods 25: 402-408 (2001). 
43) Gonzalez-Aguero M, Pavez L, Ibanez F, Pacheco I, Campos-Vargas R, Meise L.A et al., Identification of woolliness response genes in peach fruit after postharvest treatments. $J$ Exp Bot 59: 1973-1986 (2008).

44) Pegoraro C, Roggia Zanuzo M, Clasen Chaves F, Brackmann A, Luis Girardi C, Lucchetta L et al., Physiological and molecular changes associated with prevention of woolliness in peach following pre-harvest application of gibberellic acid. Postharvest Biol Technol 57: 19-26 (2010).

45) El-Sharkawy I, Mila I., Bouzayen M. and Jayasankar S, Regulation of two germin-like protein genes during plum fruit development. J Exp Bot 61: 1761-1770 (2010).

46) Brummell DA and Harpster MH, Cell wall metabolism in fruit softening and quality and its manipulation in transgenic plants. Plant Mol Biol 47: 311-340 (2001).

47) Hayama H, Ito A, Moriguchi T and Kashimura Y, Identification of a new expansin gene closely associated with peach fruit softening. Postharvest Biol Technol 29: 1-10 (2003).

48) Crisosto $\mathrm{CH}$ and Crisosto GM, Relationship between ripe soluble solids concentration (RSSC) and consumer acceptance of high and low acid melting flesh peach and nectarine [Prunus persica (L.) Batsch] cultivars. Postharvest Biol Technol 38: 239-246 (2005).

49) Crisosto $\mathrm{CH}$, Crisosto GM, Echeverria G and Puy J, Segregation of peach and nectarine [Prunus persica (L.) Batsch] cultivars according to their organoleptic characteristics. Postharvest Biol. Technol. 39: 10-18 (2006).

50) Iglesias I and Echeverria G, Differential effect of cultivar and harvest date on nectarine colour, quality and consumer acceptance. Sci Hort 12: 41-50 (2009).

51) Hemmaty S, Moallemi $\mathrm{N}$ and Naseri L, Effect of UV-C radiation and hot water on the calcium content and postharvest quality of apples. Span J Agric Res 5: 559-568 (2007).

52) Crisosto $\mathrm{CH}$, Slaughter D, Garner D and Boyd J, Stonefruit critical bruising thresholds. J Amer Pomol Soc 55: 76-81 (2001). 
53) Crisosto $\mathrm{CH}$ and Valero D, Harvesting and postharvest handling of peaches for the fresh market. in: The peach: Botany, production and uses, ed. by Layne DR and Bassi D. CAB Intl., Wallingford, UK, pp 575-596 (2008).

54) Commission Regulation (EC) No. 1861/2004.

55) Sandefur Pl, Clark JR, Peace C, Peach texture, in: Horticultural Reviews, ed. by Janick J. WileyBlackwell, Chichester, pp 241-302 (2013).

56) Sherman BW, Topp BL and Lyrene PM, Non-melting flesh for fresh market peaches. Proc Fla State Hort Soc 103: 293-294 (1990).

57) Shinya P, Contador L, Predieri S, Rubio P and Infante R, Peach ripening: segregation at harvest and postharvest flesh softening. Postharvest Biol Technol 86: 472-478 (2013).

58) Hemmaty S, Moallemi $\mathrm{N}$ and Naseri L, Effect of UV-C radiation and hot water on the calcium content and postharvest quality of apples. Span J Agric Res 5: 559-568 (2007).

59) Barka EA, Kalantari S, Makhlouf J and Arul J, Impact of UV-C irradiation on the cell walldegrading enzymes during ripening of tomato (Lycopersicon esculentum L.) fruit. J Agric Food Chem 48: 667-671 (2000).

60) Bu J, Yu Y, Aisikaer G and Ying T, Postharvest UV-C irradiation inhibits the production of ethylene and the activity of cell wall-degrading enzymes during softening of tomato (Lycopersicon esculentum L.) fruit. Postharvest Biol. Technol 86: 337-345 (2013).

61) Giovannoni J, Molecular biology of fruit maturation and ripening. Annu Rev Plant Biol 52: 725-749 (2001).

62) Mignani I, Ortugno C and Bassi D, Biochemical parameters for the evaluation of different peach flesh types. Acta Hort 713: 441-448 (2006).

63) Kao MWS, Brecht JK, Williamson JG and Huber DJ, Ripening development and quality of Melting and Non-melting Flesh peach cultivars. Hort Sci 47: 879-885 (2012).

64) A-H-Mackerness S, Surplus SL, Blake P, John CF, Buchanan-Wollaston V, Jordan BR. Thomas B, UV-B induced stress and changes in gene expression in Arabidopsis thaliana: Role of signaling 
pathways controlled by jasmonic acid, ethylene and reactive oxygen species. Plant Cell Environ 22: 1413-1424 (1999).

65) Becatti E, Petroni K, Giuntini D, Castagna A, Calvenzani V, Serra G et al., Solar UV-B radiation influences carotenoid accumulation of tomato fruit through both ethylene-dependent and independent mechanisms. J Agric Food Chem 57: 10979-10989 (2009).

66) Hayama H, Tatsuki M, Ito A and Kashimura Y, Ethylene and fruit softening in the 'stony hard' mutation in peach. Postharvest Biol Technol 41: 16-21 (2006).

67) Pressey R and Avants JK, Differences in polygalacturonase composition of clingstone and freestone peaches. J Food Sci 43: 1415-1423 (1978).

68) Manganaris GA, Vasilakakis M, Diamantidis G and Mignani I, Diverse metabolism of cell wall components of melting and non-melting peach genotypes during ripening after harvest or cold storage. J Sci Food Agric 86: 243-250 (2006).

69) Callahan AM, Scorza R, Bassett $C$, Nickerson $M$ and Abeles FB, Deletions in an endopolygalacturonase gene cluster correlate with non-melting flesh texture in peach. Funct Plant Biol 31:159-168 (2004).

70) Tucker ML, Cell wall metabolism and softening during ripening, in: Fruit Ripening: Physiology, Signalling and Genomics, ed. by Nath P, Bouzayen M, Mattoo AK. and Pech J-C. CABI, Wallingsford, pp 48-62 (2014).

71) Morgutti S, Negrini N, Mignani I, Bassi D and Cocucci M, Flesh softening and phosphorylation of soluble polypeptides in relation to ethylene production in Prunus persica fruits with different ripening patterns. Acta Hort 682: 155-162 (2005).

72) Cho H-T and Cosgrove DJ, Expansins as agents in hormone action, in: Plant Hormones: Biosynthesis, Signal Transduction, Action, ed. by Davies PJ. Kluwer, Dordrecht, pp. 262-281 (2004).

73) Hayama H, Shimada T, Haji T, Ito A, Kashimura Y and Yoshioka H, Molecular cloning of a ripening-related expansin cDNA in peach: evidence for no relationship between expansin accumulation and change in fruit firmness during storage. J Plant Physiol 157: 567-573 (2000). 
Table 1: Primer list for cell-wall analysis

\begin{tabular}{rccl}
\hline \multicolumn{1}{c}{ Gene } & Accession & Direction & \multicolumn{1}{c}{ Primer Sequence } \\
\hline \multirow{2}{*}{ Endo-PG } & GSE7145 & For & GTCATCTGGTGTCACAATC \\
& & Rev & ACCCTCAGTTGTTCCATC \\
Exp 1 & \multirow{2}{*}{16305104} & For & AAACGTTGGTGGTGCCGGTGAT \\
& & Rev & TTGCTTGCCAACCAGTCCTGGA \\
Exp 2 & \multirow{2}{*}{29466640} & For & TCCAGGACTGGTTGGCAAGCAA \\
& & Rev & TAGGACACCACTGTGCGGCCAT \\
Exp 3 & 29466642 & For & GGGTGCATGGGAAGCAGCTCAT \\
& & Rev & CCATGGTGCCAGAGGCATCAGA \\
\hline
\end{tabular}


Table 2. Changes in flesh firmness, soluble solids content (SSC), titratable acidity (TA) and ethylene emission in MF 'Suncrest', SM 'Big Top' and NMF 'Babygold 7' fruit at $\mathrm{t}_{0}$ and after $36 \mathrm{~h}$ in the absence (Control) or in the presence (UV-B) of UV-B-treatment. ${ }^{1}$

\begin{tabular}{|c|c|c|c|c|c|c|}
\hline Genotype & $\begin{array}{l}\text { Time } \\
(\mathrm{h})\end{array}$ & Treatment & $\begin{array}{l}\text { Flesh firmness } \\
(\mathrm{N})\end{array}$ & $\begin{array}{c}\text { SSC } \\
\left({ }^{\circ} \text { Brix }\right)\end{array}$ & $\begin{array}{c}\text { TA } \\
\left(\text { meq } \mathrm{NaOH} 100 \mathrm{ml}^{-1}\right)\end{array}$ & $\begin{array}{c}\text { Ethylene } \\
\left(\mathrm{nL} \mathrm{h} \mathrm{h}^{-1} \cdot \mathrm{g}^{-1} \mathrm{FW}\right)\end{array}$ \\
\hline \multirow[t]{3}{*}{ MF 'Suncrest' } & 0 & $\mathrm{t}_{0}$ & $56.9 \pm 1.24^{\mathrm{a}}$ & $13.2 \pm 0.39^{\mathrm{a}}$ & $18.6 \pm 1.84^{\mathrm{a}}$ & $5.15 \pm 0.08^{\mathrm{c}}$ \\
\hline & 36 & Control & $11.1 \pm 0.48^{\mathrm{c}}$ & $14.7 \pm 0.38^{\mathrm{a}}$ & $17.7 \pm 0.82^{\mathrm{a}}$ & $15.3 \pm 0.89^{b}$ \\
\hline & 36 & UV-B & $18.1 \pm 1.49^{b}$ & $15.2 \pm 0.15^{\mathrm{a}}$ & $10.8 \pm 0.51^{b}$ & $23.0 \pm 2.23^{\mathrm{a}}$ \\
\hline \multirow[t]{3}{*}{ SM 'Big Top' } & 0 & $\mathrm{t}_{0}$ & $57.0 \pm 2.24^{\mathrm{a}}$ & $15.3 \pm 1.75^{\mathrm{a}}$ & $7.88 \pm 0.51^{\mathrm{a}}$ & $0.35 \pm 0.06^{\mathrm{c}}$ \\
\hline & 36 & Control & $36.0 \pm 6.24^{\mathrm{b}}$ & $16.1 \pm 1.16^{\mathrm{a}}$ & $9.40 \pm 0.19^{\mathrm{a}}$ & $18.1 \pm 1.73^{\mathrm{b}}$ \\
\hline & 36 & UV-B & $34.7 \pm 4.78^{\mathrm{b}}$ & $14.6 \pm 1.27^{\mathrm{a}}$ & $8.91 \pm 0.20^{\mathrm{a}}$ & $31.2 \pm 3.20^{\mathrm{a}}$ \\
\hline \multirow[t]{3}{*}{ NMF 'Babygold 7' } & 0 & $\mathrm{t}_{0}$ & $28.3 \pm 3.95^{\mathrm{a}}$ & $8.58 \pm 0.16^{\mathrm{a}}$ & $9.01 \pm 1.37^{\mathrm{a}}$ & $93.0 \pm 12.0^{\mathrm{a}}$ \\
\hline & 36 & Control & $31.7 \pm 4.81^{\mathrm{a}}$ & $11.5 \pm 1.93^{\mathrm{a}}$ & $8.26 \pm 0.52^{\mathrm{a}}$ & $108 \pm 14.0^{\mathrm{a}}$ \\
\hline & 36 & UV-B & $28.1 \pm 2.90^{\mathrm{a}}$ & $13.3 \pm 1.21^{\mathrm{a}}$ & $7.79 \pm 0.61^{\mathrm{a}}$ & $157 \pm 37.5^{\mathrm{a}}$ \\
\hline
\end{tabular}

\footnotetext{
${ }^{1}$ Values followed by different letters indicate, within each genotype, significant differences between Control and UV-B-treated fruit according to one-way ANOVA followed by Tukey's test $(\mathrm{P} \leq 0.05)$. Values are the means $\pm \mathrm{SE}$.
} 
Table 3. Changes in the expression levels of a PpEndo-PG gene and of three PpExp genes in MF 'Suncrest', SM 'Big Top' and NMF 'Babygold $7^{\prime}$ fruit at $\mathrm{t}_{0}$ and after $36 \mathrm{~h}$ in the absence (Control) or in the presence (UV-B) of UV-B-treatment, as determined by qRT-PCR.

\begin{tabular}{|c|c|c|c|c|c|c|}
\hline \multirow{2}{*}{$\begin{array}{l}\text { Genotype } \\
\text { MF 'Suncrest' }\end{array}$} & \multirow{2}{*}{$\begin{array}{c}\text { Time } \\
\text { (h) } \\
0\end{array}$} & \multirow{2}{*}{$\begin{array}{c}\text { Treatment } \\
\mathrm{t}_{0}\end{array}$} & \multicolumn{4}{|c|}{$\begin{array}{l}\text { Relative gene expression } \\
\left(2^{-\Delta \Delta \mathrm{Ct}}\right)\end{array}$} \\
\hline & & & $\frac{P p E n d o-P G}{1.08 \pm 0.02^{\mathrm{b}}}$ & $\frac{P p \operatorname{Expl}}{1.42 \pm 0.02^{\mathrm{a}}}$ & $\frac{P p E x p 2}{1.26 \pm 0.02^{\mathrm{a}}}$ & $\frac{\text { PpExp3 }}{1.14 \pm 0.02^{\mathrm{b}}}$ \\
\hline & $\begin{array}{l}36 \\
36\end{array}$ & $\begin{array}{l}\text { Control } \\
\text { UV-B }\end{array}$ & $\begin{array}{l}11.6 \pm 0.13^{\mathrm{a}} \\
11.2 \pm 0.10^{\mathrm{a}}\end{array}$ & $\begin{array}{l}1.48 \pm 0.02^{\mathrm{a}} \\
1.12 \pm 0.01^{\mathrm{b}}\end{array}$ & $\begin{array}{l}1.26 \pm 0.02^{\mathrm{a}} \\
1.02 \pm 0.01^{\mathrm{b}}\end{array}$ & $\begin{array}{l}1.96 \pm 0.05^{\mathrm{a}} \\
1.13 \pm 0.02^{\mathrm{b}}\end{array}$ \\
\hline \multirow[t]{2}{*}{ SM 'Big Top' } & 0 & $\mathrm{t}_{0}$ & $1.50 \pm 0.09^{b}$ & $3.96 \pm 0.22^{\mathrm{a}}$ & $5.21 \pm 0.31^{\mathrm{a}}$ & $1.32 \pm 0.03^{\mathrm{c}}$ \\
\hline & $\begin{array}{l}36 \\
36\end{array}$ & $\begin{array}{l}\text { Control } \\
\text { UV-B }\end{array}$ & $\begin{array}{l}3.54 \pm 0.10^{\mathrm{a}} \\
3.45 \pm 0.17^{\mathrm{a}}\end{array}$ & $\begin{array}{l}3.62 \pm 0.05^{\mathrm{a}} \\
1.10 \pm 0.03^{\mathrm{b}}\end{array}$ & $\begin{array}{l}5.50 \pm 0.08^{\mathrm{a}} \\
1.74 \pm 0.10^{\mathrm{b}}\end{array}$ & $\begin{array}{l}3.03 \pm 0.06^{\mathrm{a}} \\
1.96 \pm 0.02^{\mathrm{b}}\end{array}$ \\
\hline \multirow{2}{*}{$\begin{array}{l}\text { NMF } \\
\text { 'Babygold 7' }\end{array}$} & 0 & $\mathrm{t}_{0}$ & ND & $3.58 \pm 0.06^{\mathrm{b}}$ & $3.12 \pm 0.10^{b}$ & $5.87 \pm 0.24^{b}$ \\
\hline & $\begin{array}{l}36 \\
36\end{array}$ & $\begin{array}{l}\text { Control } \\
\text { UV-B }\end{array}$ & $\begin{array}{l}\text { ND } \\
\text { ND }\end{array}$ & $\begin{array}{l}6.34 \pm 0.13^{\mathrm{a}} \\
1.17 \pm 0.04^{\mathrm{c}}\end{array}$ & $\begin{array}{l}6.99 \pm 0.13^{\mathrm{a}} \\
1.29 \pm 0.05^{\mathrm{c}}\end{array}$ & $\begin{array}{l}9.64 \pm 0.22^{a} \\
1.46 \pm 0.09^{c}\end{array}$ \\
\hline
\end{tabular}




\section{Captions for figures}

Figure 1. Enzyme activity of: (A) Exo-polygalacturonase (Exo-PG), (B) endo-1,4- $\beta$-D-glucanase/ $\beta$-Dglucosidase (EGase), (C) $\beta$-galactosidase ( $\beta$-Gal) and (D) pectin methylesterase (PME) in the mesocarp of MF 'Suncrest' (empty bars), SM 'Big Top' (dotted bars) and NMF 'Babygold 7' (striped bars) fruits at $\mathrm{t}_{0}$ and after $36 \mathrm{~h}$ of postharvest in the absence (C $36 \mathrm{~h}$ ) or in the presence (UV-B $36 \mathrm{~h}$ ) of UV-B treatment. Data are means \pm SE. Different letters indicate significant differences, within each genotype (lower case “Suncrest”, upper case 'Big Top', bold 'Babygold 7') according to one-way ANOVA followed by Tukey's test $(\mathrm{P} \leq 0.05)$.

Figure 2. Levels of: (A) PpEndo-PG polypeptide, (B) Endo-PG activity and (C) PpEndo-PG protein in MF 'Suncrest', SM 'Big Top' and NMF 'Babygold 7' fruit mesocarp at $\mathrm{t}_{0}$ and after $36 \mathrm{~h}$ of postharvest in the absence $(\mathrm{C} 36 \mathrm{~h})$ or in the presence (UV-B $36 \mathrm{~h}$ ) of UV-B treatment. Loading: $2 \mu \mathrm{g}$ protein per lane for SDS-PAGE experiments, $15 \mu \mathrm{g}$ per lane for native-PAGE experiments. The results of one experiment, representative of three, are shown.

Figure 3. Levels of PpExp polypeptides in MF 'Suncrest', SM 'Big Top' and NMF 'Babygold 7' fruit mesocarp at $t_{0}$ and after $36 \mathrm{~h}$ of postharvest in the absence $(\mathrm{C} 36 \mathrm{~h})$ or in the presence (UV-B $\left.36 \mathrm{~h}\right)$ of UV-B treatment. Loading: $5 \mu \mathrm{g}$ protein per lane. The results of one experiment, representative of three, are shown. 


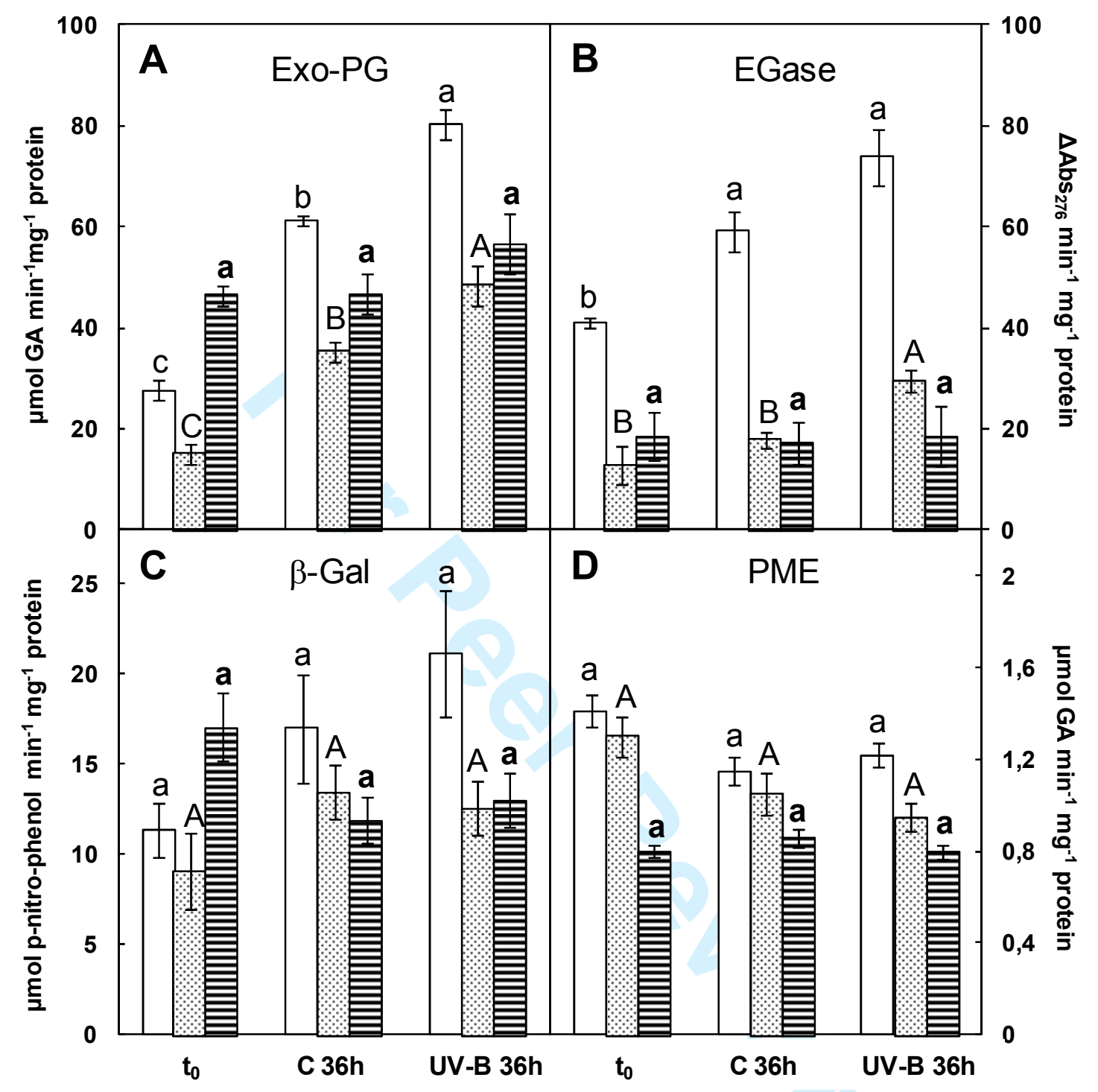

Figure 1 


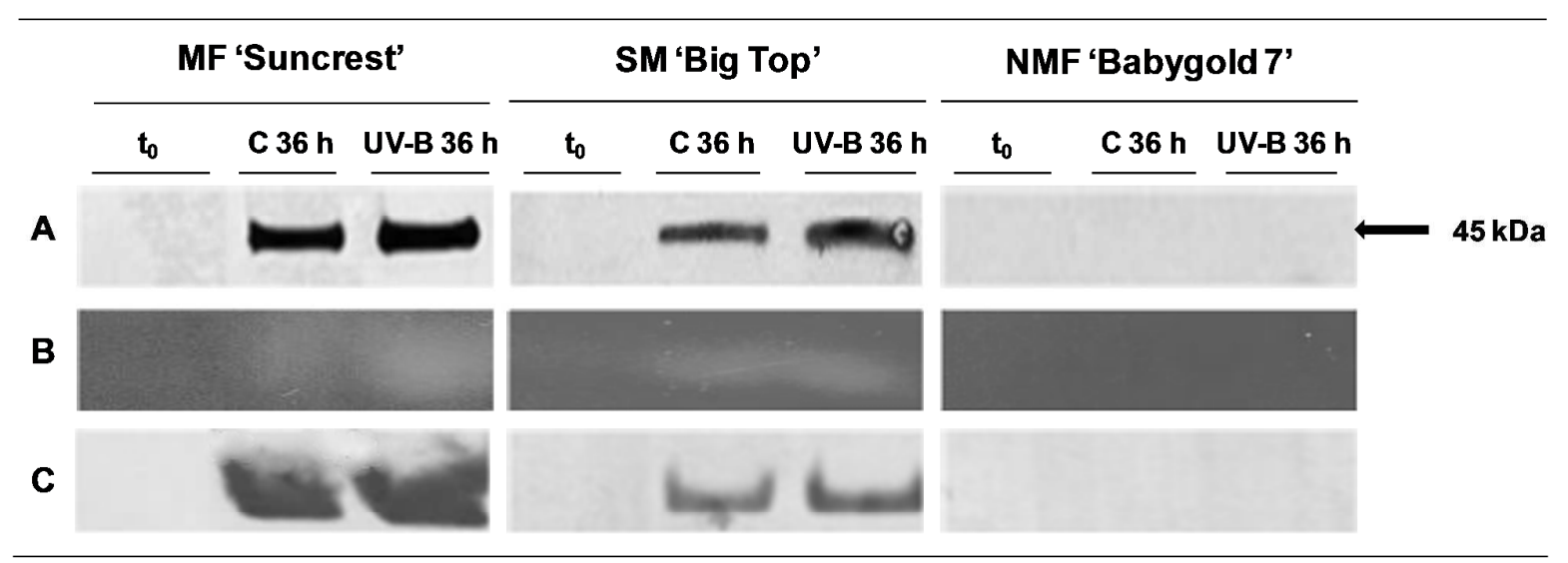

Figure 2 
